\title{
INFLUENCE OF TYPE 2 DIABETES MELLITUS ON THE PREVENTION AND TREATMENT OF PROSTHETIC STOMATITIS ${ }^{*}$
}

\author{
Badalov R. M. ${ }^{1}$, Chernyavskaya I. V. ${ }^{2}$ \\ ${ }^{1}$ Kharkov Medical Academy of Postgraduate Education, Kharkiv, Ukraine; \\ ${ }^{2}$ State Institution «V. Danilevsky Institute for endocrine pathology problems National Academy \\ of Medical sciences of Ukraine", Kharkiv, Ukraine \\ robertbadalov2994@gmail.com
}

Type 2 diabetes mellitus (DM) is one of the most common metabolic pathologies, the incidence of which is increasing every year [1-3]. About 463 million people worldwide suffer from diabetes, and this number is projected to increase by about $50 \%$ by 2045 [4]. In the world, almost 3 million deaths per year are associated with diabetes, which is equivalent to $5.2 \%$ of all mortality [5]. According to the World Health Organization (WHO), any disease with a prevalence of more than $1 \%$ should be considered as a disease of public health importance, therefore type 2 diabetes is characterized as a new epidemic [6].

As you know, type 2 diabetes is diagnosed most frequently in patients over 30 years old. As studies show, only $6.4 \%$ patients with diabetes older than 40 years preserve all natural teeth [7]. Sometimes patients who go to a dental clinic for help are not even aware of their disease. And only after oral cavity examination by a doctor who can identify oral diabetic signs, diagnostic laboratory tests are carried out for the presence of diabetes and the establishment of the main diagnosis.

Oral manifestations of type 2 diabetes are xerostomia, burning in the mouth, gingivitis, periodontal disease, dental caries, candidal and other infectious lesions [8]. These oral complications have a negative impact on the life quality of life of patients with diabetes, and can also directly or indirectly affect the glycemic profile [9].

It is generally known that hyperglycemia in diabetes mellitus is an important risk factor for vascular complications. The five classic complications associated with diabetes include retinopathy, neuropathy, nephropathy, cardiovascular complications, and delayed wound healing. Periodontal disease has recently been

* The work was carried out within the framework of the planned scientific theme of the Kharkov Academy of Postgraduate Education «Improving the quality of structural materials and improving the methods of treating dental patients» (state registration No. 0115U000146).

Institution, which financed the research: Ministry of Health of Ukraine.

The authors assume responsibility for the published work.

The authors guarantee absence of competing interests and their own financial interest when carrying out the research and writing the article.

The manuscript was received by the editorial staff 28.04.2021. 
recognized as the "sixth complication" of diabetes, which means that diabetes may contribute to the progression of periodontitis $[9,10]$.

Periodontal disease and type 2 diabetes are considered to be chronic diseases associated with habits, lifestyle, socio-economic factors and which, at their core, have a deep connection with inflammatory mechanisms [11].

Type 2 diabetes affects the onset and progression of periodontitis, causing a hyperinflammatory response, thereby disrupting bone repair processes and producing a glycation of end products [12-14]. Periodontitis as a local infection focus can cause an increase in the levels of IL-6, TNF-a and CRP in the systems, which further leads to an increase in systemic inflammation, which contributes to insulin resistance [15]. Based on a biological hypothesis, there are significant randomized controlled trials (RCTs) that show that periodontal treatment can improve glycemic control [16]. However, two well-designed large-scale RCTs have reported conflicting results on whether periodontal treatment affects glycated hemoglobin $(\mathrm{HbA} 1 \mathrm{c})$ in patients with T2DM or not [17, 18].

The state of the oral cavity in patients with type 2 diabetes differs significantly from the state of similar tissues of healthy individuals, which leads to the chronic development of periodontal disease, and, as a consequence, to the progressive destruction of the supporting tissues of the teeth, their loss due to extensive destruction of the alveolar bone, and, accordingly, a defect in the dentition [19].

Orthopedic treatment of patients who suffer from type 2 diabetes with removable plate prostheses is a rather sophisticated process: adaptation to prostheses is often sophisticated by prosthetic stomatitis, xerostomia, which breaks the fixation and stabilization of removable denture constructions during functional occlusions of biting and chewing, which in turn accele- rates the processes of prosthetic tissues lodges atrophy [20].

During orthopedic treatment with removable denture constructions in patients with type 2 diabetes, acrylic prosthetic stomatitis often occurs, which, in addition to local toxic-allergic and traumatic effects, also have general somatic significance [21].

Long-term difficult wound healing in patients with type 2 diabetes is associated with many factors, including impairment of various immunity links. With an inflammatory-destructive process in the tissues of the periodontium, immunological reactions develop, mainly in the system of local immunity of the oral cavity [20]. In this regard, the treatment of defects of the dentition in patients with type 2 diabetes is still a difficult and urgent problem, requiring the search for new methods to optimize orthopedic care for this category of patients.

Since patients with type 2 diabetes take a quite large number of different drugs to correct blood glucose levels, lipid metabolism and other disorders, the use of chemicals for the prevention and treatment of prosthetic stomatitis in them is irrational. In this regard, the most appropriate is the use of herbal preparations, in particular Echinacea purpurea (Echinacea purpurea).

We have previously shown that one of the etiological factors of prosthetic stomatitis are fungi of the genus Candida [22]. In view of this, it is also advisable to use antimycotic drugs that reduce the intensity of seeding and stop the mycotic component, namely clotrimazole in the form of a cream.

Purpose of the study: study the effect of type 2 diabetes on the state of the mucous membrane and tissues of the oral cavity to optimize prevention and increase the effectiveness of dentition defects complex treatment in this contingent of patients.

\section{MATERIALS AND METHODS}

112 patients with type 2 diabetes were examined mild to moderate severity at the age of 35 to 64 years old who came to the clinic for the purpose of prosthetics.

Among the complications of diabetes that most often prevailed in the examined patients were the following: polyneuropathy in 47 patients (42.0\%), encephalopathy in 31 patients (27.7\%), angiopathy of the lower extremities in 14 patients (12.5\% of patients), diabetic retinopathy in 35 patients (31.3\%), among them with the proliferative form -2 patients. 
Nephropathy, as a complication of diabetes, was diagnosed in 12 patients (10.7\%).

All studies were carried out in accordance with the requirements of the Helsinki Declaration of Human Rights (1964) and the additional protocol to the Biomedical Research Convention and Ukrainian legislation (2005).

At the time of treatment, all examined patients were under the supervision of an endocrinologist, received oral antihyperglycemic drugs and were able to compensate for carbohydrate metabolism. The degree of carbohydrate metabolism compensation was assessed by the parameters of fasting glycemia, postprandial glycemia, and the level of glycosylated hemoglobin (HbA1c).

All patients received full or partial removable dentures from acrylic plastics. Patients were divided into groups depending on the method of prosthetic stomatitis prevention. Thus, Group I (control) included 36 patients (17 men and 19 women), the average age was 54 years, who did not receive a prophylactic course of therapy for prosthetic stomatitis; Group II - 42 patients (20 men and 22 women), mean age -56 years, who were prescribed a prophylactic course of Echinacea Compositum S $(2.2 \mathrm{ml}+20 \mathrm{ml}$ of water $)$ in accordance with the instructions for its use. Group III consisted of 34 patients (14 men and 20 women), mean age -52 years, who received a course of Echinacea Compositum $\mathrm{S}$ inside $(2.2 \mathrm{ml}+20 \mathrm{ml}$ of water) and, in addition, the application of $1 \%$ Clotrimazole cream under the bases of prostheses for 1 month. twice a day after breakfast and at night. No adverse reactions were observed when using the above drugs. Patients of all three groups, during the previous 2 months, did not take anti-inflammatory and antimicrobial drugs, there was no prescription for mouthwash in the anamnesis.

Glycemic indices during the day, including fasting blood glucose, postprandial glycemia were determined by the glucose oxidase method using an express analyzer «Biosen $\mathrm{C}$ line», $\mathrm{HbA} 1 \mathrm{c}$ - by the colorimetric method.

Morphological studies were performed by biopsy, after the patients' written consent to the study. The assessment of the capillaries resistance was carried out using the Kulazhenko sample.

To assess the state of the oral mucosa, the Yasinovsky test was used.

The state of the oral cavity local immunity in patients with type 2 diabetes was assessed by the content of secretory immunoglobulin $\mathrm{A}$ (S-IgA) and lysozyme activity of saliva.

The concentration of S-IgA was determined in the oral fluid by enzyme immunoassay using kits of reagents «IgA secretory-ELISA» from "XEMA».The determination of the lysozyme activity of saliva was carried out by the spectrophotometric method [15]. Content researchS$\operatorname{IgA}$ in the oral fluid and lysozyme activity of saliva were carried out in dynamics: before the start of prosthetics, on days 6-7, days 25-30, days 90-120 after the end of treatment.

Statistical processing was carried out using the STATISTICA 6.1 application package. Compliance with the parameters of the normal distribution was checked using the ShapiroWilk test. To test the statistical significance of intergroup differences, the nonparametric Mann-Whitney test was used.

The significance of differences was taken into account at $\mathrm{p} \leq 0.05$.

\section{RESULTS AND THEIR DISCUSSION}

Morphological studies of the prosthetic bed tissues of the in patients with type 2 diabetes before the start of treatment revealed a complex of metabolic and structural changes in the arterioles and capillaries of the papillary and reticular layers of the gums connective tissue base. In the epithelium of the gums mucous membrane, dystrophic changes in cells with an initial expansion of interepithelial spaces, moderate infiltration with microflora elements, neutral leukocytes and lymphocytes were revealed; fungi of the genus Candida, cocci (Fig. 1).

Vascular changes were manifested by varying degrees of microangiopathies development: disorganization of connective tissue, sclerosis and hyalinosis of small vessels.

The mucous membrane of the prosthetic beds in patients with type 2 diabetes was characterized by atrophy, which was clinically manifested by dryness, leading to its increased trauma and long-term adaptation to prostheses (Fig. 2). 


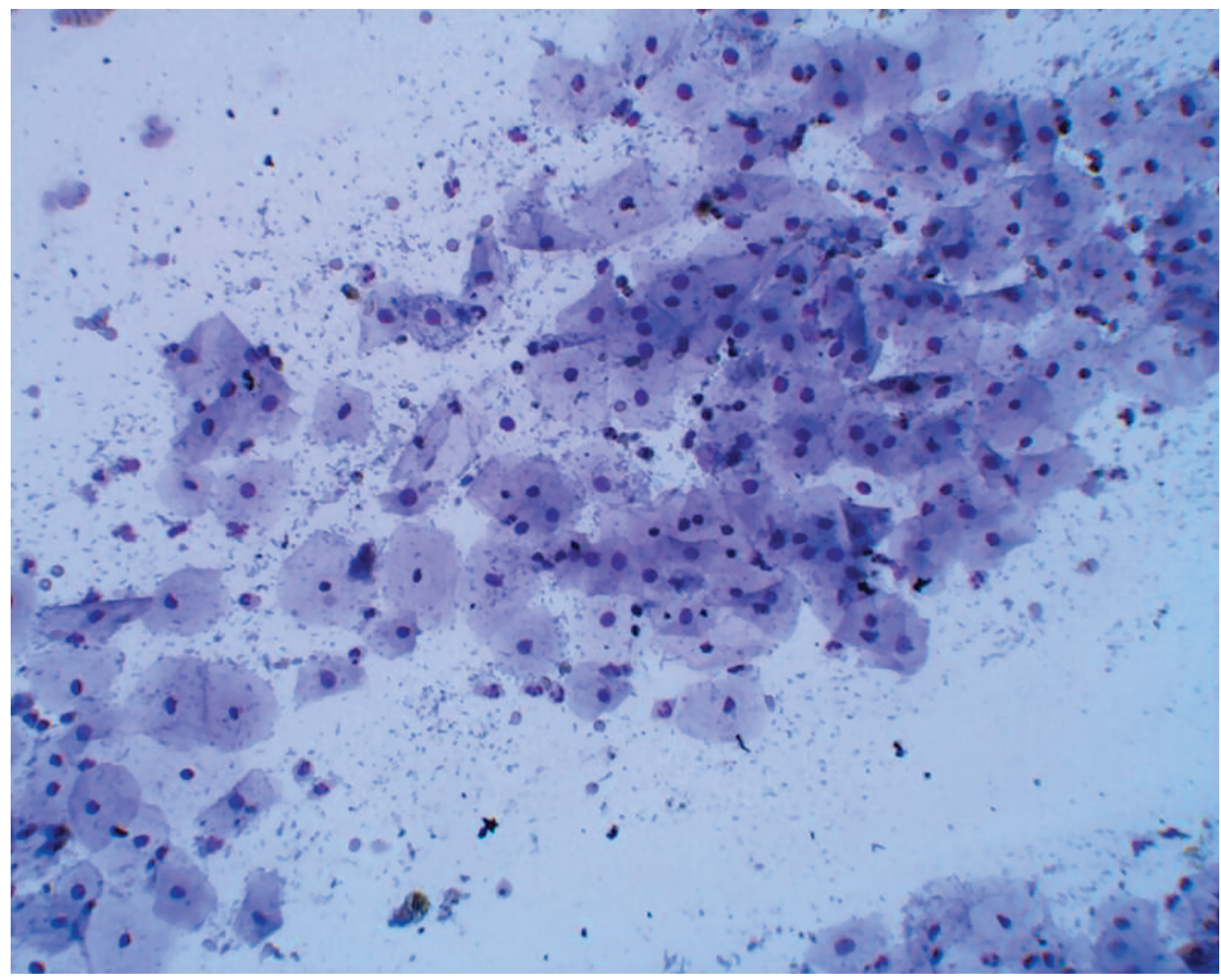

Fig. 1. Epithelium of the gingival mucosa in a patient with type 2 diabetes. Hematoxylin-eosin staining $(\times 90)$.

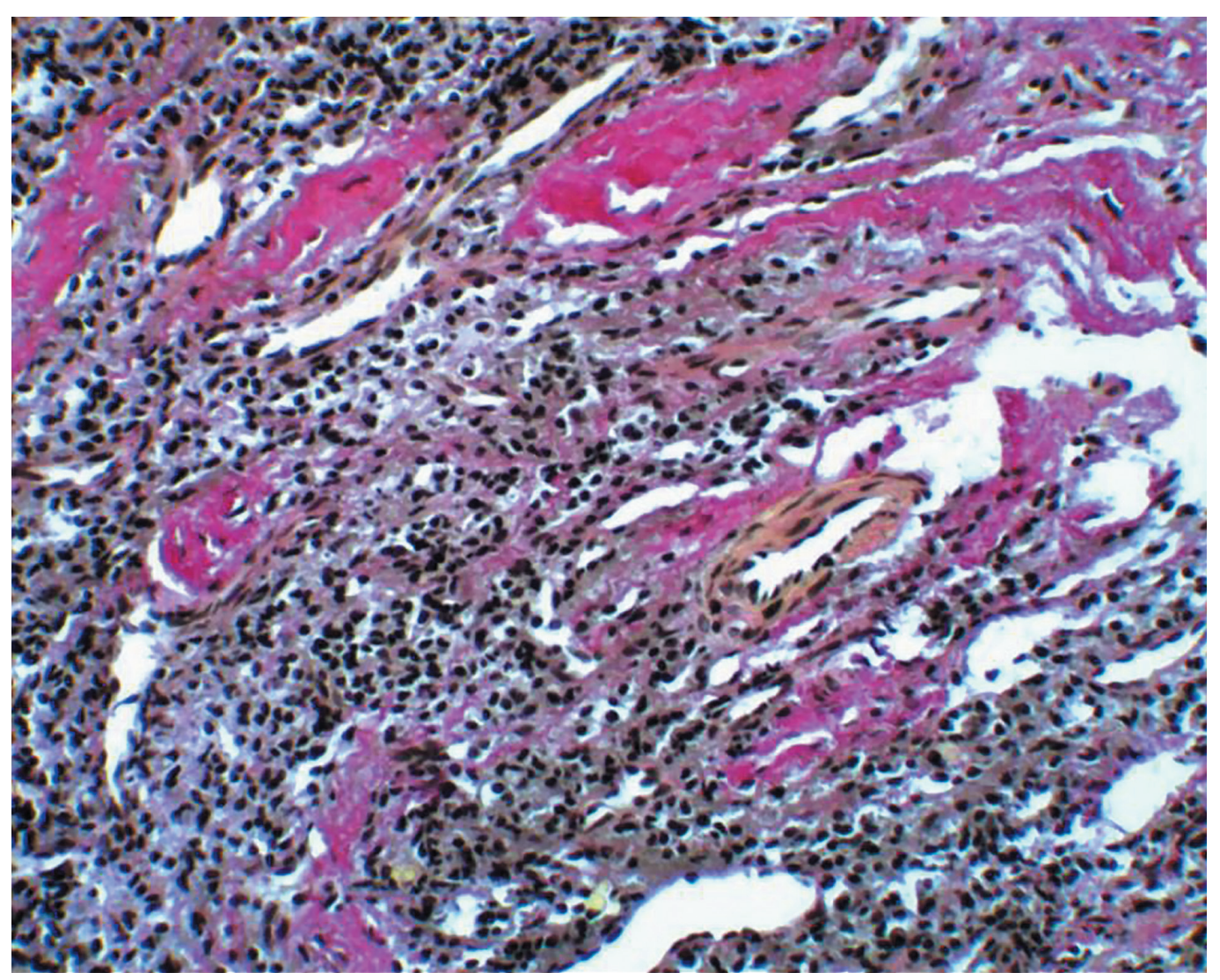

Fig. 2. Thickening of the walls of the capillaries of the mucous membrane of the prosthetic bed in a patient with type 2 diabetes. Coloring according to Van Gieson $(\times 90)$. 


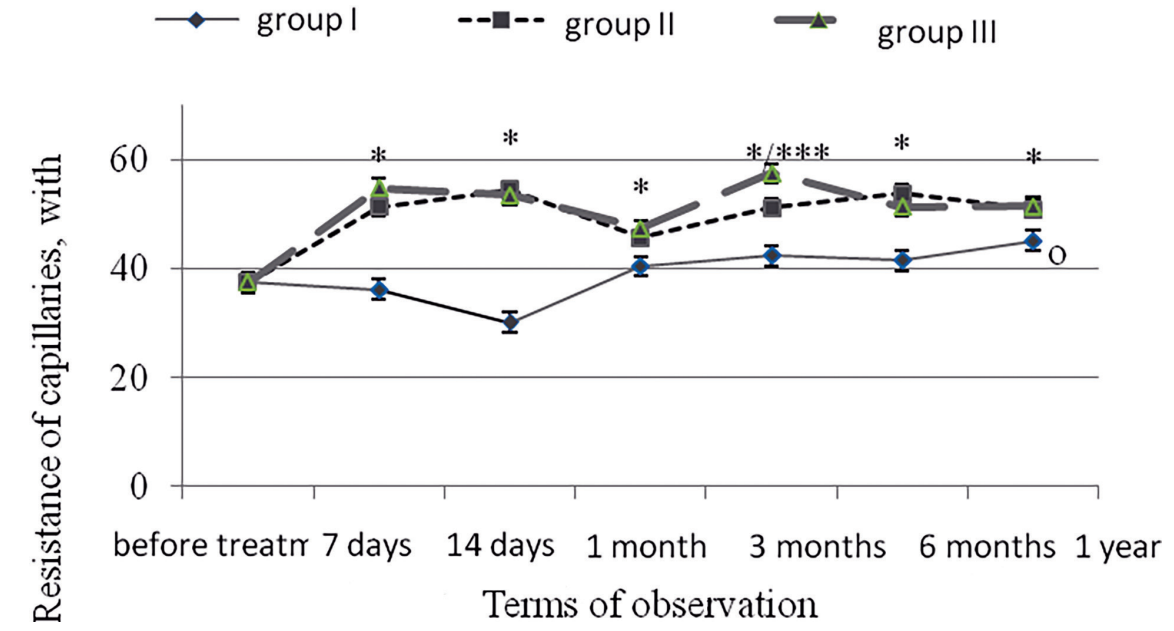

Fig. 3. Dynamics of changes in the resistance of the capillaries of the oral mucosa in patients with type 2 diabetes.

Note: o - reliability in comparison with the data before prosthetics;

* - reliability in comparison with group I;

$* * *$ — reliability in comparison with group II.

$\longrightarrow$ group I $\quad \longrightarrow$ group III

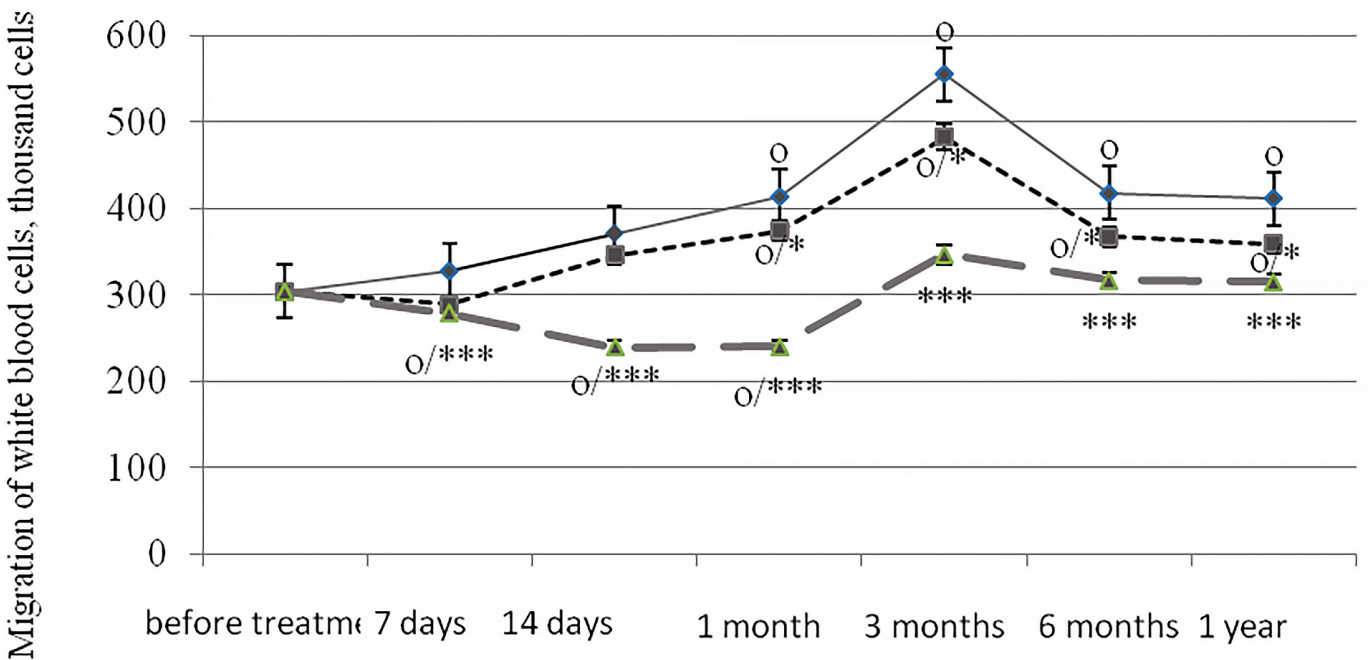

Terms of observation

Fig. 4. Dynamics of changes in the migration of oral leukocytes in patients with type 2 diabetes.

Note: o - reliability in comparison with the data before prosthetics;

* - reliability in comparison with group I;

$* * *$ _ reliability in comparison with group II.

In patients with type 2 diabetes, an increase in the degree and depth of erosive and ulcerative lesions of the mucous membrane and chronic inflammation were revealed.

The morphological study of biopsy material in patients in group III showed that 6 months. after the imposition of prostheses, acanthosis was determined in the epithelium, and rough sclerosis was found in the area of acanthotic cords. A year later, acanthotic strands pene- trated deeply into the lamina of the mucous membrane itself.

In patients of group II, the thickness of the epithelial layer was reduced, the acanthotic cords were loose, with a large amount of connective tissue stroma.

In cases of plate prostheses imposition and a combination of applications under the basis of Clotrimazole cream with the therapeutic use of Echinacea Compositum S in the III group, 
changes in the tissues of the mucous membrane were minimal and approached the physiological state.

The mucous membrane of the prosthetic beds of the patients of three groups was examined for capillary resistance within 7, 14 days, 1, 3, 6 months and 1 year (Fig. 3).

The resistance of the capillaries practically did not change on the first day after treatment. After 14 days, the vascular resistance increased by $19.5 \%$. In more distant terms, restoration of the vascular wall was observed up to $35 \%$.

During the treatment with prostheses with prophylactic and therapeutic use of Echinacea Compositum S (group II), their resistance increased to $51.33 \pm 0.12 \mathrm{~s}$, which is $27.1 \%$ higher than before prosthetics. In the more distant terms of prosthetics in this group of patients, no significant changes in capillary resistance were observed.

Less variable changes in indicators were typical for group III (see Fig. 3). Such dynamics testifies to the effect of Echinacea Compositum S on the restoration of capillary resistance.

Thus, treatment with a prophylactic course of local therapy made it possible to restore the resistance of the capillaries.
The results of the study of the migration leukocytes are shown in Fig. 4.

Thus, prosthetics in patients of all three groups did not cause a sharp increase in the number of leukocytes in the swabs. The number of leukocytes in the period from 14 days up to 1 month in group 1 significantly increased by $26.3 \%$, which amounted to $414.5 \pm 34.1$ thousand cells. In group II, the number of leukocytes increased more gradually — by $18.4 \%$ and amounted to $374.2 \pm 24.1$ thousand cells.

When using local preventive therapy, a decrease in the number of leukocytes was observed by $26.8 \%$ to a level of $240.9 \pm 28.3$ thousand cells. The dynamics of this decrease had already stabilized by the end of the 3rd month, but in contrast to the 1st and 2nd groups, in the 3rd group with the use of complex prophylaxis, the leukocyte counts fluctuated within the values before prosthetics, while in the 1st subgroup after 1 year there was a difference from indicator to prosthetics by $34.6 \%$ $411.2 \pm 22.1$ thousand cells.

The dynamics of epithelial desquamation in type 2 diabetes patients using removable dentures was obtained at the same time $(7,14$ days, 1, 3, 6 months and 1 year) (Fig. 5).

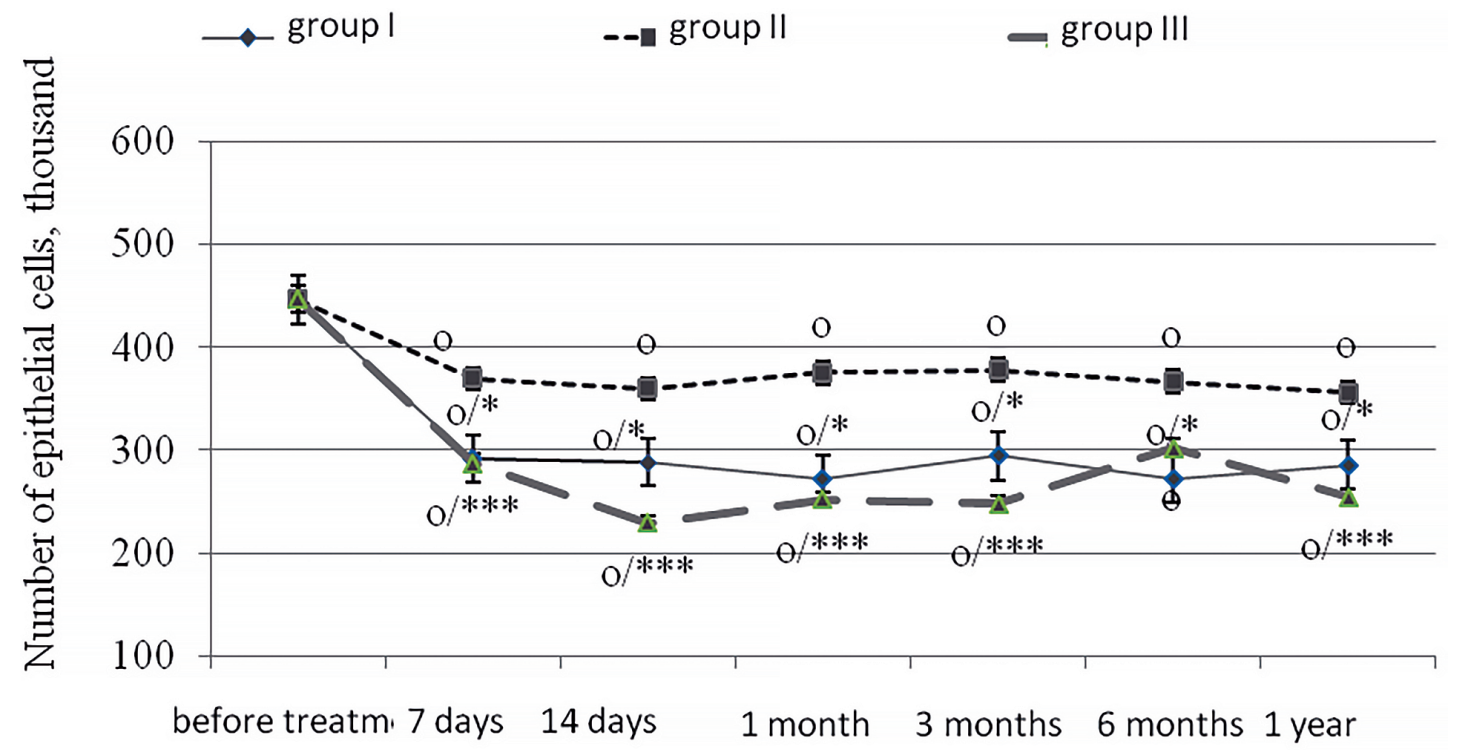

Terms of observation

Fig. 5. Dynamics of changes in the rate of desquamation of epithelial cells from the mucous membrane in patients with type 2 diabetes

Note: o - reliability in comparison with the data before prosthetics;

* - reliability in comparison with group I,

$* * *$ — reliability in comparison with group II. 


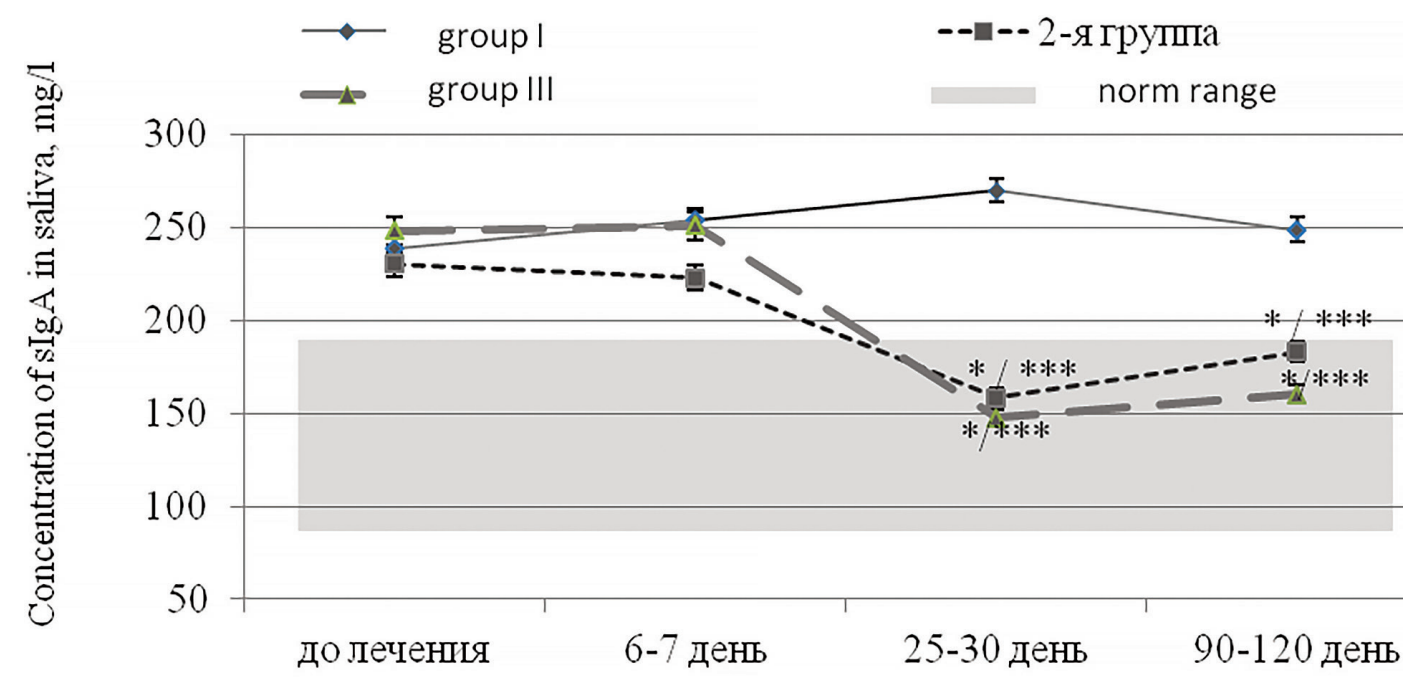

Terms of observation

Fig. 6. Dynamics of changes in S-IgA concentration in patients with type 2 diabetes.

Note: * - significant intergroup differences $(\mathrm{p} \leq 0.05)$;

$* * *$ — significant differences before and after treatment.

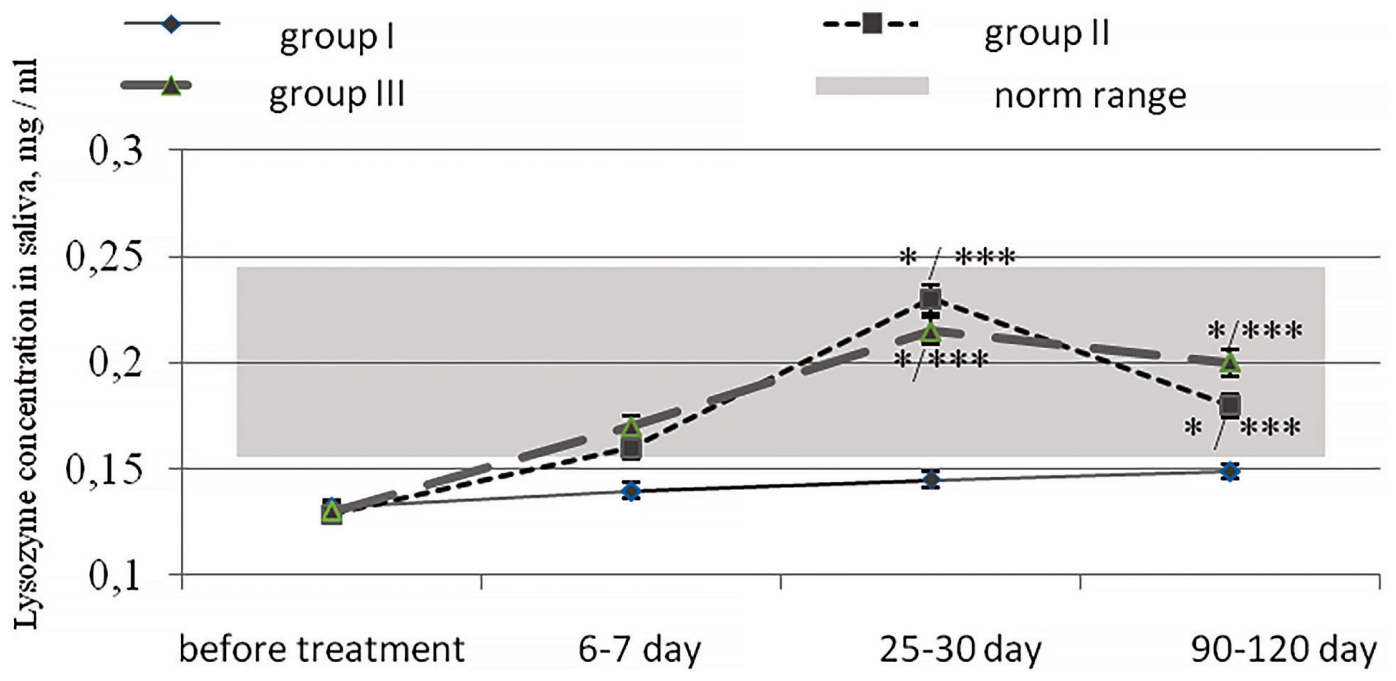

Terms of observation

Fig. 7. Dynamics of the level of lysozyme in the oral fluid in patients with type 2 diabetes

Note: * - significant intergroup differences $(\mathrm{p} \leq 0.05)$;

$* * *$ — significant differences before and after treatment.

In the II group of patients, the inhibition of the epithelialization process was less pronounced (a significant decrease by $17.3 \%$ to the level (369.2 \pm 22.7$)$ thousand cells) and later, up to 1 year of using prostheses, the number of desquamated epithelial cells was restored to the value before prosthetics - $(412.5 \pm 33.0)$ thousand cells.

In the third group, the combination preparation Echinacea Compositum S and applications under the bases of prostheses $1 \%$ cream
Clotrimazole restored the process of epithelialization. To assess the local immunity of the oral mucosa, the humoral factors of immunity were studied - the concentration of S-IgA and lysozyme [23] (Fig. 6).

Before the start of prosthetics, the S-IgA content was elevated in all patients. A decrease in the S-IgA level was detected on the 25-30th day of treatment.

In group I, without the use of a prophylactic course of therapy, the concentration of S-IgA in 
saliva remained at a high level at all stages of research.

In all patients with type 2 diabetes before treatment, the content of lysozyme in saliva was significantly reduced (Fig. 7).

The use of Echinacea Compositum $\mathrm{S}$ for a week in patients of group II caused an increase in lysozyme by $24 \%$, and the combined use of Echinacea Compositum S with applications of $1 \%$ Clotrimazole cream led to an increase in lysozyme content by $30.7 \%$.

Thus, the changes occurring in the body of patients with type 2 diabetes lead to functional and morphological changes in tissues and organs, which inevitably affects the state of both the tissues of the oral cavity and the entire dentoalveolar system $[9,11,19]$.

The obtained data indicate that the method of comprehensive prevention and rational pros- thetics of patients with type 2 diabetes mellitus allows to avoid the occurrence of such complications as prosthetic stomatitis and significantly reduce the degree of periodontal inflammation holding the teeth clasp.

Determination of changes in the concentration of S-IgA and the content of lysozyme in the oral fluid can be prognostic for understanding the severity of inflammatory reactions when using removable acrylic dentures with the simultaneous appointment of a preventive course of local therapy in the form of $1 \%$ Clotrimazole cream and Echinacea Compositum S applications in patients with type 2 diabetes, which will reduce the degree of the inflammatory process and indicate a significant preventive and high clinical effect of treatment.

\section{CONCLUSIONS}

1. It has been established that type 2 diabetes leads to changes in the oral mucosa and significantly complicates the provision of dental care.

2. When assessing the dental status of patients, a prerequisite is the identification of disorders of carbohydrate metabolism.
3. In the prevention and treatment of patients with type 2 diabetes, it is advisable to use the Echinacea Compositum S complex of drugs and $1 \%$ Clotrimazole cream in order to have a positive effect on the pathogenetic mechanisms and development of microangiopathies.

\section{REFERENCES}

1. 100 Izbrannyh lekcij po jendokrinologii (vtoroj vypusk); pod red. Karachenceva JuI, Kravchun NA, Il'inoj IM, Har'kov, 2015;2: 456 p.

2. Mikitjuk MR, Hizhnjak OO. Sulima TN. Saharnyj Diabet 2014; 17 (1):70-74. http://doi.org/10.14341/ DM2014170-74.

3. Jendokrinologija; pod red. Dedova II, Mel'nichenko GA, Moskva, 2018: 832 p.

4. IDF. Diabetes Atlas, 9th ed, Brussels, 2019: 176 p.

5. Einarson TR, Acs A, Ludwig C, Panton UH. Cardiovasc Diabetol 2018;17: 83. http://doi.org/10.1186/s12933-0180728-6.

6. World Health Organization. Diabetes country profiles, 2016, available at: http://www.who.int/diabetes/ country-profiles/ukr_en.pdf?ua=1 .

7. Izuora KE, Ezeanolue EE, Neubauer MF, et al. J Clin Translat Endocrinol 2016; 4: 28-31. http://doi.org/ 10.1016/j.jcte.2016.02.003.

8. Bangash RY, Khan AU, Tariq KM, et al. Pak Oral Dent J 2012; 32: 296-299.

9. Ira BL. US Endocrinol 2012; 8: 93-97. http://doi.org/10. 17925/USE.2012.08.02.93.
10. Al-Maskari AY, Al-Maskari MY, Al-Sudairy S. Sultan Qaboos Univ Med J 2011;11: 179-186.

11. Peter S, Izakovicova HL. Biomedical Papers 2014; 158(1): 35-38. https://doi.org/10.5507/bp.2014.005 .

12. Chee B, Park B, Bartold PM. Int J Evidence Based Healthcare 2013; 11(4): 317-329. http://doi.org/10.1111/ 1744-1609.12038.

13. Stumvoll M, Goldstein BJ, van Haeften TW. Lancet 2005; 365(9467): 1333-13346. https://doi.org/10.1016/ s0140-6736(05)61032-x.

14. Lalla E, Papapanou PN. Nat Rev Endocrinol 2011; 7(12): 738-748. https://doi.org/10.1038/nrendo.2011.106.

15. Graziani F, Gennai S, Solini A, Petrini M. J Clin Periodontol 2018; 45(2): 167-187. https://doi.org/10.1111/ jcpe.12837.

16. Engebretson S, Kocher T. J Clin Periodontol 2013; 40(14): 153-163. https://doi.org/10.1111/jcpe.12084.

17. Engebretson SP, Hyman LG, Michalowicz BS, et al. JAMA 2013; 310(23): 2523-2532. https://doi.org/10.1001/ jama.2013.282431.

18. D'Aiuto F, Gkranias N, Bhowruth D, et al. Lancet Diab Endocrinol 2018; 6(12): 954-965. https://doi.org/10.1016/ s2213-8587(18)30038-x. 
19. Cicmil S, Mladenović I, Krunić J, et al. J Dent Med 2018; 22: 7-14

20. Trentin MS, Verardi G, De C Ferreira M, et al.J Contemp Dent Pract 2017; 18: 107-111. Goncharova A. I., Zemko V. Ju., Okulich V. K. Immunopatologija, allergologija, infektologija 10.5005/jp-journals-10024-1999.

21. Daniel R, Gokulanathan S, Shanmugasundaram N, et al. J Pharm Bioallied Sci 2012; 4: 280-282.
22. Badalov RM. Problemy bezpererunoi' medychnoi' osvity ta nauky 2011; 1: 80-86, available at: http://nbuv.gov. ua/UJRN/Psmno_2011_1_21.

23. Goncharova AI, Zemko VJu, Okulich VK. Immunopatologija, allergologija, infektologija 2018; 1: 34-41. https://doi.org/10.14427/jipai.2018.1.48.

\section{INFLUENCE OF TYPE 2 DIABETES MELLITUS ON THE PREVENTION AND TREATMENT OF PROSTHETIC STOMATITIS}

Badalov R. M. ${ }^{1}$, Chernyavskaya I. V. ${ }^{2}$

${ }^{1}$ Kharkov Medical Academy of Postgraduate Education, Kharkiv, Ukraine;

${ }^{2}$ State Institution «V. Danilevsky Institute for endocrine pathology problems National Academy of Medical sciences of Ukraine», Kharkiv, Ukraine

robertbadalov2994@gmail.com

Purpose: to study the effect of type 2 diabetes mellitus on the state of the mucous membrane and tissues of the oral cavity to optimize the prevention and increase the effectiveness of dentition defects complex treatment in this contingent of patients.

Materials and methods. We examined 112 patients with type 2 diabetes mellitus aged 35 to 64 years, who were further divided into three groups. The state of the oral mucosa, morphological changes, local immunity, lysozyme were determined. The work used morphological, microscopic methods, enzyme immunoassay and spectrophotometry. To test the statistical significance of intergroup differences, the nonparametric MannWhitney test was used.

Results. Oral use in patients with diabetes mellitus type 2, applications of $1 \%$ Clotrimazole cream and Echinacea Compositum S had a positive preventive and therapeutic effect, which was accompanied by an increase in capillary resistance, a decrease in the degree of migration of leukocytes, an increase in the functional activity of immune system cells and an increase in the level of regenerative processes. In patients with defects in the dentition against the background of type 2 diabetes mellitus, violations of the oral cavity local immunity were revealed, characterized by a significant increase in the S-IgA content and a decrease in lysozyme. Orthopedic treatment with partial removable denturesled to a significant decrease in the concentration of S-IgA and an increase in the bactericidal activity of saliva due to increased lysozyme synthesis. It was concluded that type 2 diabetes mellitus affects the state of the oral mucosa, which must be taken into account when providing orthopedic and dental treatment.

Keywords: type 2 diabetes mellitus, oral cavity, prevention, treatment. 


\title{
ВПЛИВ ЦУКРОВОГО ДІАБЕТУ 2 ТИПУ НА ПРОФІЛАКТИКУ ТА ЛІКУВАННЯ ПРОТЕЗНИХ СТОМАТИТІВ
}

\author{
Бадалов Р. М. ${ }^{1}$, Чернявська I. В. ${ }^{2}$
}

${ }^{1}$ Харківська медична академія післядипломної освіти, м Харків, Україна;

${ }^{2}$ Державна установа "Інститут проблем ендокринної патологї ім. В. Я. Данилевського

Національної академії медичних наук України»,

м. Харків, Україна

robertbadalov2994@gmail.com

Мета: вивчення впливу цукрового діабету 2 типу на стан слизової оболонки і тканин ротової порожнини для оптимізації профілактики і підвищення ефективності комплексного лікування дефектів зубних рядів у цього контингенту хворих.

Матеріали та методи. Обстежено 112 паціентів із цукровим діабетом 2 типу віком від 35 до 64 років, які в подальшому були розподілені на три групи. Визначали стан слизової оболонки ротової порожнини, морфологічні зміни, локальний імунітет, лізоцим. В роботі використані морфологічні, мікроскопічні методи, імуноферментний аналіз і метод спектрофотометрії. Для перевірки статистичної значущості міжгрупових відмінностей використовували непараметричний критерій Манна-Уїтні.

Результати. Застосування в ротовій порожнині у пацієнтів із цукровим діабетом 2 типу аплікацій $1 \%$ крему Клотримазол і препарату Echinacea Compositum S надавало позитивний профрілактичний та лікувальний ефекти, що супроводжувалося підвищенням стійкості капілярів, зниженням ступеня міграції лейкоцитів, підвищенням функціональної активності клітин імунної системи і збільшенням рівня регенеративних процесів. У паціентів із дефектами зубних рядів на тлі цукрового діабету 2 типу виявлено порушення локального імунітету ротової порожнини, які характеризуються достовірним підвищенням вмісту S-IgA і зниженням лізоциму. Ортопедичне лікування частковими знімними протезами призводило до достовірного зниження концентрації S-IgA і збільшення бактерицидної активності слини за рахунок посилення синтезу лізоциму. Зроблено висновок, що цукровий діабет 2 типу впливає на стан слизової оболонки ротової порожнини, що необхідно враховувати при наданні ортопедичного, стоматологічного лікування.

К лючові слов а : цукровий діабет 2 типу, ротова порожнина, профілактика, лікування.

Бадалов Р. М.

ORCID, https://orcid.org/0000-0003-3623-1655

Чернявська I. В.

ORCID, https://orcid.org/0000-0002-4834-3972 